\title{
SOCIAL MEDIA: A NEW FORM OF LOBBYING
}

\author{
IIhem GARGOURI*
}

\begin{abstract}
The objective of this article is to show that social media is a new form of lobbying called "e-lobbying". Indeed, in the last decades, social media, such as "Facebook", "Twitter", "yootube", and "Instagram" have participated enormously in political, economic and social life. Today, the e-lobbying is certainly one of the most powerful lobbies that exert great influence on the decision-maker. Consisting of social networks, the e-lobbying tries to influence the largest number of Internet users worldwide in order to exert pressure on the decision maker. With the development of Internet techniques, the e-lobbying has truly imposed itself as a new form of pressure group and an indispensable tool for the exercise of democracies. E-lobbying has become a central part of the political, economic and social areas, that is why, it is important to know which social networks are the most used worldwide. E-lobbying tries to influence the public opinion in order to defend ideas or, on the contrary, to fight against the decisions of the decision maker. For example, this new form of lobbying has greatly contributed to the achievement of the Tunisian revolution and the destruction of Ben Ali regime. Other forms of lobbying, such as the Tunisian General Labor Union (UGTT) or the opposition parties, did not succeed in facing the dictatorship of President Ben Ali.
\end{abstract}

Keywords: e-lobbying; influence strategy; political party; Unions, democracy; Tunisia

DOI 10.53373/ REDS.2022.55.2.0060

\section{Introduction}

In a democratic environment, or more precisely, a sovereign people's environment, political parties and pressure groups have complete freedom to criticize the government decisions. The absence of political and social pressure kills democracy. The function of governing is given to a single actor who makes all decisions, whether political, economic or social. Demonstrations are absent in dictatorial regimes because of the non-existence of a strong opposition.

The role of the government is to intervene in all areas, whether political, economic or social. It is essentially concerned with the general interest of the whole country. Therefore, it is obliged to find solutions to the various problems that may exist in all areas. In a word, the government controls everything and reconstitutes the mechanisms of the failing field.

The economy is considered one of the most important examples of government intervention in an increasing number of areas. The search for better economic results is the main concern of the government: the revival of economic activity helps to solve many political and social problems. Indeed, if the economy is healthy,

* Doctor of Economics, University of Sfax (Tunisia), e-mail: ilhemgargouri@gmail.com. 
opposition parties and pressure groups will find no criticism to make. Similarly, if the unemployment problem is solved, the social situation of individuals will improve significantly.

The government determines the economic policy to be followed. There are two main alternatives: the plan and the market. The government decides whether it wants the solutions to be centralized or decentralized. If it chooses the former, it must tell firms what to produce. But if it chooses the latter, it must let the market play its role in determining production and prices.

We know that politicians and pressure groups can intervene in any area where they feel change is needed. These interventions are frequently used in the economic field since there are very sensitive issues such as unemployment which is the main indicator of the existence of an economic crisis.

Rising unemployment, economic recession and trade offensives by other countries are issues that inflame and animate the political world. Opposing parties and pressure groups are the first to benefit from the economic problems since it makes it easier for them to criticize and sabotage the government. For example, international trade problems that affect a country's economic interests present fertile ground for opposition parties to say that the government is primarily responsible for the conflict and is not capable of resolving it: the agricultural conflict negotiated during the Uruguay Round led the French government into a politically dangerous territory.

The opposition parties are always on the lookout for the country's bad economic situation so that they can blame everything on the government. These parties attack the government where it is weakest, especially in the economic sphere: the rise in unemployment, for example, is an issue of great importance to the opposition parties. Indeed, the latter are trying to show the main cause of the existence of this problem and that this government should not be trusted. Therefore, the opposition parties are exploiting the economic difficulties to weaken the government and manipulate public opinion.

In politics, nothing is certain, everything is uncertain. We live in an aggressive world where, for each political party, all tricks are allowed: betrayals, provocations, rumors, slander, traps, etc. So, challenging the opponent, exploiting crises and accidents, using pressure groups to sabotage a project are the rules of the game between political parties. Each party sets up its pawns. The strategies used are, in most cases, aggressive and selfish, since the essential objective is to reach power, even if it means exploiting the country's economic situation or certain pressure groups.

Thus, the electoral game of parties encourages political warfare. The government must resist all strategies of the opposition parties as well as those of the pressure groups that engage in the political process in order to protect the economic interests of the national industries they represent. Some parties play the card on the table with the party in power, others play indirectly by acting discreetly. In the election campaigns, the political parties present projects full of solutions to all the 
economic and social problems: they mainly talk about solving the problem of unemployment, ensuring social protection, reducing taxes, increasing salaries, etc. Each party, therefore, makes promises in order to influence the public opinion and win the maximum number of votes.

In order to raise the maximum amount of money for their election campaigns, politicians choose commercial policies that interest the pressure groups. This is the principle of give and take between politicians and lobbyists: the financial support given by the lobbyist forces the politician to return the favor by obeying the demands of the lobby.

Lobbying can be defined as the fact of carrying out interventions intended to influence directly or indirectly the elaboration, application or interpretation of legislative measures, norms, regulations and more generally, any intervention or decision of public authorities (Farnel 1994). This lobbying can take the form of trade unions, opposition parties or civil societies.

But, in recent decades, we have noticed the appearance of a new form of lobby thanks to the development of new information and communication technology. This new form of lobby is represented by social media, which has changed the whole world. Indeed, social networks have become a great power by playing the role of lobby in all areas. The existence of several types of social media has influenced the opinions of Internet users: through social media, one can defend interests, private or not, exerting pressure or influence on individuals and companies or even governments in power.

In this article, we will study the different lobbies that exist in Tunisia while showing that social media represents a new form of lobby. Indeed, the classical lobbies are formed by trade unions, religious groups and civil societies. In the case of Tunisia, the Tunisian General Labor Union (UGTT) is the most powerful lobby that has been exerting pressure on the government since its creation. The UGTT, which has a certain capacity for social protest, organized general strikes several times during Bourguiba's presidency, leading to the "Black Thursday" riots of 1978 and the "bread riots" of 1984.

But, these classical lobbies could not eliminate the dictatorship of Ben Ali. It is, in fact, with the advent of social media that we saw the emergence of the Tunisian revolution.

In the first part of this article, we will analyze the role and objectives of political parties and lobby while presenting the different pressure groups that exist in the political, economic and social fields. In the second part, we will present the two strategies adopted by the classic lobbies to exert pressure on the government. The third part of this article will present the new form of lobby that is formed by social media while showing its importance in political, economic and social life. In the last part, we will analyze a questionnaire that shows the importance of social media in the political life of Tunisia. 


\section{Role of political parties and the lobby}

\subsection{Definition of a political party}

According to the political scientist Burdeau (1991), "a party is any grouping of individuals who, professing the same political views, strive to make them prevail, both by rallying the greatest possible number of citizens and by seeking to conquer power or, at least, to influence its decisions. This definition gives us a clear idea of the function and objectives of political parties. Conquering power or influencing it seems to be the main concern of political parties. This preoccupation has animated the political world through the use of aggressive strategies: each party plays all possible cards, even immoral ones, in order to attain power or to destabilize the opposing parties.

A political party can be the expression of a specific social class, or it can adopt certain ideologies. Each party aims to attract the maximum number of voters by choosing the right candidate for the elections: political parties become more and more active at election time in order to get voters to vote for them.

Political parties differ from each other in their ideologies and principles. Indeed, each political party chooses from the start its own ideology or ideologies: the French Socialist Party (SP) does not have the same ideology as the Union Of France (UDF) party or more generally the ideologies of the Left are quite the opposite of the ideologies of the Right. The political party which presents one or several effective ideologies will have more chances to attract the maximum of voters. On the other hand, the one that presents an ideology that has not been successful should change ideology and try to find another one that guarantees a good popularity.

The strategic calculation of political parties forces them to choose two strategies: the first is to specialize in a single ideology, while the second is to opt for a diversification of ideologies. The political party that opts for a single ideology risk playing to a single homogeneous political market, i.e., to a single category of people (e.g., youth, peasants, workers, etc.). On the other hand, the political party that diversifies its ideologies can easily play on heterogeneous political markets, that is, on several categories of people. Thus, during elections, the political party that is based on several ideologies has a better chance of winning more votes than the political party that is based on a single ideology. The diversification of ideologies is a mandatory strategy if the political party wants to increase its election probability. It is better to have several heterogeneous political markets than one homogeneous political market.

In the elections, each candidate presents his or her proposals to govern the country, giving solutions to the most serious problems such as unemployment, social protection, social housing, etc. The political players play on the social side to sensitize the voters and show them that when they are elected, unemployment and exclusion, for example, will be easy social problems to solve. Political players have realized that it is necessary to play on the sensitivities of voters that are influenced by social issues. 
Economic policy decisions are often determined by political issues. Indeed, it is mainly the player in power who makes several important economic policy decisions that will set the strategy to be followed, whether on a national or international scale. The economic situation of the country is the main concern of the political players who are going to run for an election: in the programs of the candidates for the election, we always hear promises such as "our economy must be more powerful", "for a social balance", "unemployment must be solved", "for an economic growth", etc.

\subsection{Definition of lobbying}

The word lobbying can have several names such as "interest representation" or "advocacy".We can identify behind each of these terms a multitude of actors who use it: companies, professional organizations, trade unions, associations, cults, public actors, etc (Foucraut 2019).

A lobby is a pressure group that defends the interests of a social or economic group. Its objective is to exert pressure on the State authorities in order to reach a solution to the problem posed. Some economists consider the lobby as a monopolistic group that has certain common characteristics and whose only function is to go to extremes to defend the interests of this group. Lobby groups are therefore the intermediary between economic and social interests and the political decision. They are the center of communication with the government of the day and they exert a lot of influence on trade policies and even on international trade negotiations.

Generally, lobbying takes two forms: internal lobbying consisting of personal contacts and external lobbying consisting of public awareness. But lobbying can be interpreted in two ways: regular and irregular. For example, "in France, lobbying has a bad image, referring to a secret, shady, underhanded activity that promotes particular interests against the general interest. Conversely, in the United States, lobbying is institutionalized and lobbying activities are regulated and can be carried out in a public manner" (Polère 2007). Lobbying (or influence communication) suffers in France from a strong negative connotation, accused of defending the particular interest against the interest of all (Bardon et al. 2012).

The question that arises is whether lobbying positively contributes to a democratic life or not. According to Vergniolle de Chantal et al. (2008), lobbying is the blind spot in the theory of democracy. Indeed, the role of lobbying can be diverted in a direction that works against democracy. Arroyo (2004) argues that some would lump lobbying in with bribery and corruption. For example, through the pursuit of self-interest, some lobbyists may betray their partners by forming a deal with the decision maker. So, beware of dishonest lobbies that seek only their own personal interests while forgetting or neglecting the general interest of all participants in the lobby.

We should also point out that there is a close relationship between politicians and lobbyists. Indeed, Foster (2021) states that informational theories argue that 
lobbyists provide politicians with information about the quality of strategies, while quid pro quo theories argue that lobbyists trade value goods for political favors: existing work assumes that lobbyists target their friends, apparently supporting informational theories.

Lobbyists can be added to the family of opposition players as they play against the player in power by creating disruptions in the decisions made. They can act legally, politically, economically and socially at the same time. Their interventions depend on the decision that the player in power has made and that they have judged to be unfavorable for certain people. It is the social side that is seen in most of the demonstrations that lobbyists organize against the player in power.

There are several kinds of lobbies that exert social pressure on the government. Among these lobbies are trade unions, religious groups and associations that deal, for example, with environmental issues, poverty and exclusion. Any group or association is capable of becoming a pressure group. But the importance of pressure varies from one group to another. Indeed, the most powerful pressure groups are the trade unions, which deserve a special importance in the political, economic and social life. Trade unions are represented by a group of people who defend their professional interests. The creation of trade unions came from the struggle of a working class to obtain better working conditions. The trade union movement was launched at the end of the 19th century: the premises of the workers' struggle appeared in Great Britain with the corresponding societies. Their aim was to defend the interests of workers. In France, the crisis of 1847 provoked workers' demonstrations.

Thus, it was with the labor struggle that the unions saw the birth of their movement. In 1899 Marshall argued that "a strong union, led by far-sighted men with a great sense of responsibility, is able in a few minutes to settle innumerable small disputes which would have caused great loss of time as well as trouble.... In this case, we may safely conclude that unions on the whole facilitate business" (Marshall, 1899, pp.381-382 cited in Freeman and Medoff, 1984 p.14). The various unions, which represented almost all economic and social activities, then became the primary force of all pressure groups since they were able to change the government's decision.

The unions often appear as a lobby against the public power. They always try to defend the interests of a group of people by criticizing the government's decision. This defense can go as far as the strategy of strike or demonstration in the streets. Most of the time, trade unions seek an increase in wages or an improvement in working conditions. They may also participate indirectly in international trade negotiations by pressuring the government to choose a trade policy that is in the interests of their members. The government cannot make a decision without being wary of the unions' reactions. The strategies of the unions are often selfish and see only the interest of a certain number of people, even if the welfare of the country as a whole is reduced: the use of a strike in one branch of the economy or even of a general strike can cause disruptions in economic and social life. 
Religious groups can act, without being players in political life, as pressure groups: believers attack laws that are not in conformity with the principles of religion, such as the law on abortion. While based on faith, these believers come together to defend religious and social interests: the churches have largely defended the interests of certain social classes, especially the poorest. The fact that there is a separation between religious groups and the state explains the existence of certain disagreements about laws that affect religion and social life.

Since the government is turning a deaf ear, the only thing left to do is to call for demonstrations in the streets in order to improve the living conditions of some people. "My friends, let's wake up! Enough indifference! This is the war! The war of defense against the misery attacking the whole universe of men.... Together we have to destroy the misery that attacks the whole planet.... Many municipalities, and more than all, those of some big cities, betray by refusing their shelter to the weakest. France must no longer leave empty houses or empty offices, nor especially let habitable places be destroyed without immediate necessity, which is abominable and even criminal. France must build immediately... and for all. It has the means, the money, the technology, the manpower, the soil..." declared Abbé Pierre on February 1, 1994 on RTL (Le monde 3/2/1994 page 11).

Thus, Abbé Pierre tries to awaken awareness on the dramatic situation of the most suffering class while solemnly drawing the attention of the government to help, for example, the homeless who have experienced a whole series of failures in their professional and social life. The strategy of these religious groups is to play on humanitarian morality and solidarity. Among these groups, we can cite the Catholic Relief Services or the Catholic Committee against Hunger and for Development (CCFD), which have always criticized government policy towards the poorly housed and fought against exclusion.

The other pressure groups are generally concerned with environmental problems, poverty and exclusion. These pressure groups are mostly represented by associations. Indeed, there are associations for the defense of animals that are endangered, such as whales, baby seals, bears, etc. The defense of the environment mobilizes the inhabitants and disturbs the realization of the programs of freeways which threaten the landscapes: under the pressure of the inhabitants, projects of freeways were delayed and sometimes completely blocked. Therefore, environmental associations often demonstrate against the creation of a motorway that disturbs the life of certain animals or against the implantation of a polluting factory.

Other associations react to the governmental measures against poverty and exclusion. The objective of these associations is to stop evictions, to house those who are homeless and to improve the legislation. The associations also put pressure on the government to take care of the homeless: the association "Right to Housing" in France acts as a trade union for the poorly housed and lobbies on legislation.

There are also other associations that deal with other subjects such as consumer associations that have the goal of obtaining better information on products while demanding that the player in power improve the living conditions of consumers. 


\section{Strategies adopted by the lobby}

Two strategies are used by lobbies when they want to defend the interests of certain individuals: the first strategy is cooperative while the second is noncooperative. The use of these two strategies is linked to the election campaign periods and the final result of the election. But in addition to these two strategies, lobbyists can use illegal strategies to get what they want. The cooperative strategy consists in supporting political players during their election campaign. Indeed, pressure groups participate in the electoral campaign by helping the politicians in any way they can, either directly or indirectly. Much of this support is in the form of financial aid, which politicians consider the most important support. This shows that the relations of the pressure groups with the candidates in the election have a great influence on the final result.

This cooperative strategy aims to influence the elected politician in the choice of trade policy. The lobbyists prefer to take their chances by choosing a cooperative strategy that allows them to safeguard and preserve their own interests. However, this strategy is risky and cannot guarantee all lobbyists the desired satisfaction. Indeed, pressure groups run great risks by financing the electoral campaign of politicians since only one candidate will be elected. Not all lobbyists will benefit from the advantages offered by the elected politician, but only those who have supported the politician. Thus, in this strategy, the politicians are at an advantage over the lobbyists because the lobbyists play first without being sure that their politician will be elected. The financial support, which the lobbyists offer, necessarily comes before the election, but the politician can return the favor only when elected.

The lobby uses a non-cooperative strategy when the politician supported during the election campaign is not elected. The cooperative strategy is thus replaced by a non-cooperative strategy that follows the final outcome of the election. This strategy, which is aggressive, consists in contesting the decisions of the elected politician who will only follow the commercial policy of the pressure groups that supported him. It is therefore the pressure groups that did not support the elected politician that will use this strategy.

The main weapon that these pressure groups have in social conflicts is the strike. The strategy used by pressure groups is often an aggressive one based on the threat of strikes and demonstrations in the streets. Indeed, in order to make their dissatisfaction with a decision taken by the government known, pressure groups may act brutally if the government does not find a solution to their protests. This aggressive strategy is used especially against the player in power who also adopts an aggressive decision that worsens the situation of a certain number of actors in economic or social life.

The intervention of pressure groups can disrupt the functioning of the economic and social system by carrying out the threat of a strike, which can sometimes lead to a general strike if the government's decision affects all activities, especially the most 
sensitive ones. The strike, which is a useful weapon for the pressure group movement, is therefore the most used strategies by pressure groups. This strategy can lead to demonstrations on the public highway and sometimes to scenes of violence. These actions are often disruptive to the economic life and may affect some users, and for this reason the measures taken by pressure groups are severely criticized by the government in place and by public opinion, especially if it is a question of a strike related to transport or roadblocks.

Thus, the strategy of pressure groups is selfish, since it is only interested in the interests of certain people while denying the general interest: the demands of pressure groups may be in opposition to the well-being of everyone. In contrast, the player in power is only interested in the general interest of his country, even if it means sacrificing the interests of a certain number of people: the general interest prevails over the particular interest.

Apart from the two cooperative and non-cooperative strategies that can be used in a visible way, there is another illegal strategy that pressure groups use to secure a better trade policy for themselves. Dishonest lobbyists are willing to use any strategy, whether legal or illegal, to protect their own interests. Indeed, lobbyists may use illegal methods to obtain a trade policy that suits them: for example, pro-protectionist industries pay bribes to political players to ensure that they get good tariff protection.

Thus, in order to obtain the desired trade policy, lobbyists first adopt a cooperative trade strategy of supporting political players during their election campaigns. Then they adopt a non-cooperative strategy when they find out that the supported player is not elected. Finally, they may sometimes use illegal strategies when neither cooperative nor non-cooperative strategies have worked.

Social problems cannot be separated from politics, as they are the main driving force behind the political game. It is mainly the player in power who faces pressure from trade unions and associations that defend the social interests of a certain number of people. The pressure groups attack the player in power when the latter makes a decision that is unfavorable to them: certain policies adopted by the player in power can lead to demonstrations and strikes that disrupt the economic life of the country. This sometimes forces the player in power to change their policies or decisions when faced with strong pressure from the lobby.

In France, among the most powerful unions, we find the General Confederation of Labor (G.C.L), the French Democratic Confederation of Labor (F.D.C.L), Force worker (F.W), the French Democratic Confederation of Christian Workers (C.F.D.T.C), the General Confederation of Executives (C.C.E), the National Confederation of Farmers' Unions (N.C.F.U). These unions act to defend a cause and try to exert influence on the player in power so that the latter chooses a policy that goes with their interests. During the Uruguay Round negotiations, most of the French unions reacted against the American proposals that wanted to reduce the export of European grain and that affected the interests of French farmers. 


\section{Social media: a new form of lobbying}

Social media is enjoying great popularity around the world. It represents a source of opportunity for all individuals and it operates on a question and answer basis. Through conversation, this media can be used in all fields, be it political, economic or social. Indeed, one can use social media for professional reasons in order to contribute to the notoriety of the brand or for political reasons within the framework of an electoral campaign or for social reasons in order to lobby through the organization of demonstrations in the streets.

Generally speaking, when we talk about social media, we are talking about "Facebook", "Twitter", "Linkedin", "YooTube" or "Instagram". Social media provides an opportunity for individuals to connect and interact with others. People interact by linking bilaterally and in thematic groups. There are two types of social media: "mainstream" social media such as "Facebook" and professional social media such as "Linkedin". The "general public" social media is the most used by Internet users. While professional social media are mainly used between companies for business and marketing activities and is known as "Business to Business" (B 2 B), in the form of "personal branding", networking or "social selling".

Social media is, therefore, a knowledge base fed and moderated by Internet users. This media can be designed in a cooperative or non-cooperative logic, allowing users to share their knowledge on a given field or to find relevant information. Each type of media presents a communication channel and opportunities for Internet users in different specialties that relate to political, economic and social domains. For example, for companies, the "social media strategy" is to plan and organize actions on social media in order to achieve marketing and commercial objectives.

For the year 2020, "Google", "Youtube" and "Facebook" are still the most visited websites. Indeed, these three American sites dominate the social media market. According to figures provided by SimilarWeb, the social network "YooTube" has the highest average session time with 23 minutes per visit. Internet users use "Facebook" for an average of 11 minutes, "Google" for 10 minutes and "Netflix" for 9 minutes.

In 2019 , out of the 7.6 billion people worldwide, there are 4.1 billion internet users for 3.3 billion active people on social networks, or $43 \%$ of the world's population. The four most used social media by Internet users are "Facebook" with 2.2 billion, "YouTube" and "WhatsApp" with 1.5 billion each and "Instagram" with 1 billion. Other social media are "Tumblr" with 794 billion users, "Qzone" with 563 million, "Twitter" with 335 million, "Reddit" with 330 million, "Baidu Tieba" with 300 million, "LinkedIn" with 260 million, "Snapchat" with 255 million and "Pinterest" with 200 million users.

With more than two billion users per month in 2019, the blue social network "Facebook" represents the most used share of social media worldwide. Regarding 
Tunisia, there are 7,300,000 "Facebook" accounts in 2019. As for the social network "Facebook Messenger", it presents the first messaging application in the world with 1.3 billion users. The social network "Wechat", which is bought by "Facebook", occupies the second place with almost the same figure. Other social networks include Wechat with 938 million users, QQ (the most used in China) with 861 million users and Skype with 300 million users.

\section{E-lobbying: a strategy of influence}

De Beaufort (2019) shows that e-lobbying has supplanted lobbying of public institutions and companies. E-lobbying has become a new pressure group that directs public opinion to indirectly influence the decision maker. E-lobbying has led to a broadening of the forms of lobbying, especially through the development of new technologies related to the IT sector. This new form of lobbying does not belong to any organization such as trade unions or political parties. It is enough to introduce information on one of the social networks to attack the decision maker. Any citizen can use this new form of influence to put pressure on the government or a political party.

E-lobbying is a pressure group that launches information all over the world through the different social networks in such a way that it cannot be controlled on a national scale. The speed of information is an important asset for this new form of lobbying as it can quickly influence public opinion. The mission of e-lobbying is to exert pressure through the dissemination of information that may be true or false. The main thing is to attack the opponent by any means using high-tech computer tools.

E-lobbying" consists in the implementation of influence strategies that are carried out by any individual or group of individuals seeking their own private interests. The acceleration of new techniques linked to the Internet is transforming the modes of communication and benefits not only the business world, but also all political, economic and social actors. The degree of influence of "e-lobbying" has become greater than other forms of pressure groups such as trade unions or civil societies.

\section{The importance of social media in Tunisia}

In recent decades, we have noticed the presence of a new form of lobby represented in the form of social media including "Facebook", "Twitter" and "Instagram". Indeed, if we take the example of the Tunisian revolution of 2011, we can see that social media has participated enormously in the destruction of the regime of the "dictator Ben Ali" and the birth of a democratic transition in Tunisia. It is essentially "Facebook" that is the main engine of this new form of lobby. This revolution led to Tunisia's first democratic legislative and presidential elections in 2014.

The main purpose of this new form of lobbying is to search and share information and photos, videos or other types of media on the web. The ability to leave information and comments on social media has played an important role in the manipulation of public opinion as the fall of "the dictatorship" of President Ben Ali in Tunisia in 2011. 
Internet users connect around common interests. For example, at the end of the 2010 decade, the majority of Tunisian citizens formed an interest group with the aim of overthrowing the political regime of President Ben Ali: the sharing of information, criticism and videos helped a lot in the success of the Tunisian revolution.

Today, social media is increasingly used in our lives. The most dominant social media are "Facebook", "Instagram", "Linkedin" and "Messenger". They are constantly evolving, both in terms of the number of users and features. It is from the 2000s that social media has developed in Tunisia: "LinkedIn" (2003), "Facebook" (2004), "YouTube" (2005), "Twitter" (2006), "WhatsApp" (2009), "Instagram" (2010), "Snapchat" (2011) and "Messenger" (2011).

\subsection{Questionnaire}

To show the importance of social media in the political, economic and social life in Tunisia, a questionnaire was conducted and distributed to 700 people. After filtration, we obtained 605 valid answers. We will focus on the most important questions of our questionnaire. The first remark we can make is that all the participants have an account on one of the social networks. The second remark we have to point out is that the social network "Facebook" is used by all the participants: "Facebook" occupies the first place. This confirms the results provided by SimilarWeb in 2020.

\subsection{Descriptive analysis of the questionnaire}

We will now proceed to a descriptive analysis of our questionnaire. Indeed, we have four factors which are: social media (SM), opposition parties (OP), trade unions (SYND) and civil societies (CS).

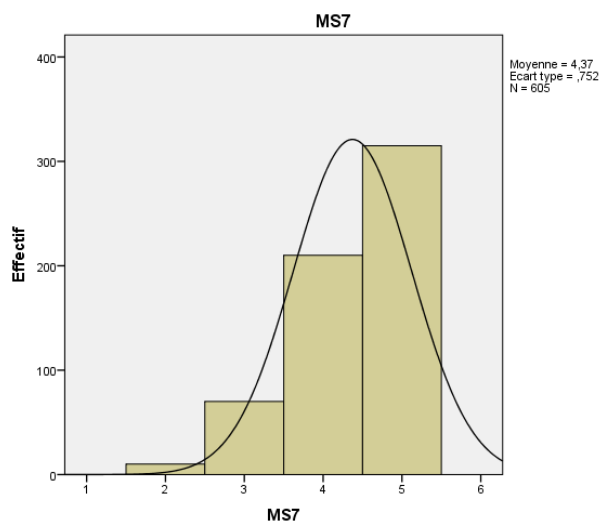

Figure 1: Histogram item (7) "social media" variable 
Regarding the first factor which is "social media", it should be noted that this variable has seven items of which we present the seventh item for the 605 observations. Item 7, whether social media can be a powerful lobby or not, has a mean of 4.37 with a standard deviation of 0.752 . Its sample distribution is weakly skewed left-skewed $($ Skewnes $=-0.966<0)$ and a platykurtic kurtosis $($ Kurtosis $=-$ $0.219<0)$.

The results show that social media is a powerful lobby capable of influencing the government decision (mean $=4.37$ : between good and very good). This new form of lobbying, which has been called "e-lobbying", has become one of the first pressure groups in Tunisia. This is obvious since social media have been very much involved in the fall of President Ben Ali and the emergence of the "Arab Spring" revolution. The influence exerted by "e-lobbying" has diverted the public opinion towards the search for true democracy and freedom of expression.

For the second factor, which is "opposition parties", it should be noted that this variable has six items, of which we present the second item for the 605 observations. Item 2, which is a measure of the degree of confidence in the government, has an overall mean of 1.76 with a standard deviation of 0.803 . This distribution is weakly skewed right-skewed $($ Skewnes $=0.645)$ and a platykurtic kurtosis $($ Kurtosis $=-$ 0.596).

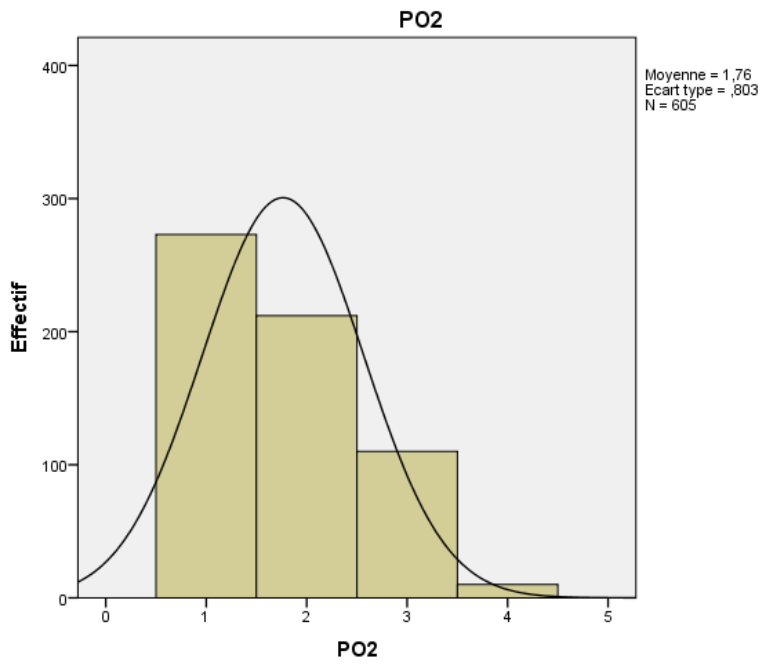

Figure 2: Histogram item (2) variable "opposition parties

The results show that respondents do not have much confidence in the government (mean $=1.76$ : between very low and low). This is explained by the instability of the government's decisions, which have led to multiple economic and social crises. In addition, the government has not provided effective solutions for the coronavirus problem: the government is powerless to limit the spread of this 
pandemic. Tunisians are tired of the political conflict between the president of the government and the president of the Republic.

Item 6, whether the opposition parties can constitute a powerful lobby or not, has a mean of 3.0 with a standard deviation of 1.078 . This distribution is weakly skewed left $($ Skewnes $=-0.166)$ and a platykurtic flattening $($ Kurtosis $=-0.361)$.

The results show that the opposition parties exert average pressure on the government (mean $=3$ : mean). This means that the opposition parties do not have a significant weight on the Tunisian political scene. This is explained by the high number of political parties in Tunisia (more than 200 parties) and the lack of a single strong political party capable of influencing the government decisions. The weakness of the opposition parties is justified by the existence of many political parties that have existed only on paper and have not presented candidates in the elections; others have been stillborn parties.

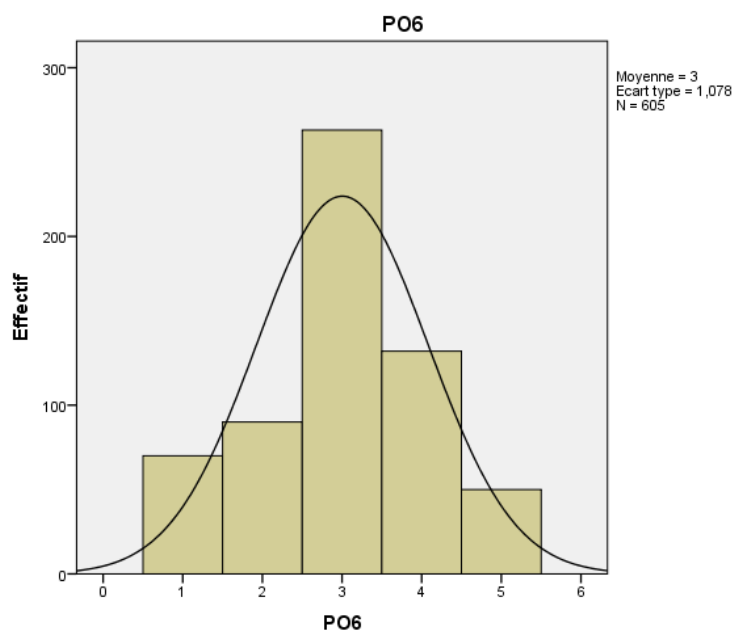

Figure 3: Histogram item (6) variable "opposition parties

Regarding the third factor, which is "unions," it should be noted that this variable has six items of which we present the sixth item for the 605 observations. Item 6 , whether unions can be a powerful lobby or not, has a mean of 3.97 with a standard deviation of 0.855 . This distribution is weakly skewed left-skewed (Skewnes = 0.900 )and leptokurtic flattening (Kurtosis $=1.240>0$ ). 


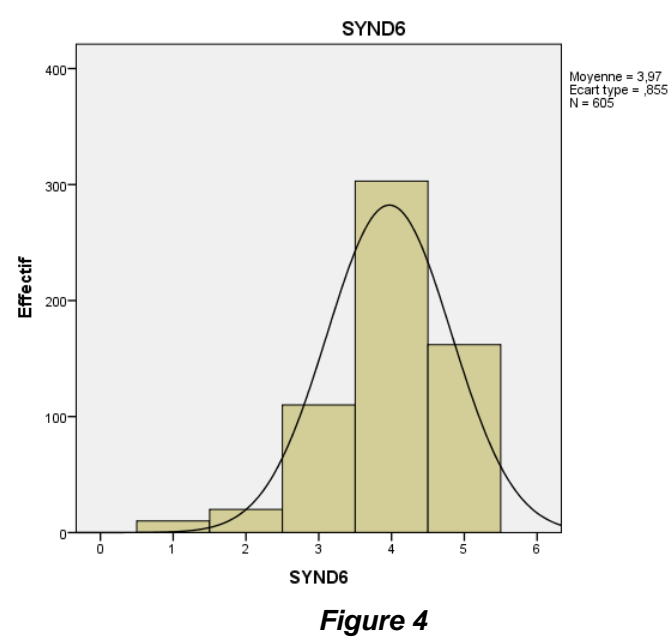

The results show that the unions exert a good deal of pressure on the government $($ Mean $=3.97$ : good). This is probably explained by the existence of a strong trade union called the "General Union of Tunisian Workers" (UGTT), whose role is to protect the interests and rights of the various social categories. This union was one of the components of the quartet of national dialogue that won the Nobel Peace Prize 2015 for its success in the mission that led to the holding of presidential and legislative elections and the ratification of the new Constitution in 2014.

For the fourth factor which is "civil societies", we should note that this variable has six items of which we present the second item for the 605 observations. Item 6 , which is whether civil societies can be a powerful lobby or not, has a mean of 2.79 with a standard deviation of 1.152 . This distribution is weakly skewed left-skewed $($ Skewnes $=0.146)$ and a kurtosis $=-0.944$.

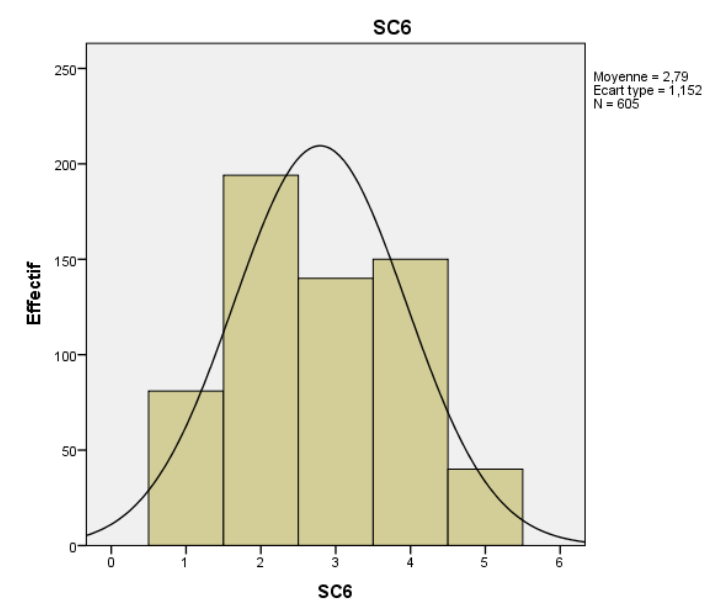

Figure 5: Histogram item (6) variable "civil societies 
The results show that civil societies exert below average pressure on the government (Mean $=2.79$ : between low and medium). Indeed, civil societies played a major role in the development of the new constitution. Civil societies were involved in creating several socioeconomic reforms to ensure peace and stability in Tunisia. The Tunisian revolution of 2011 has given more freedom to the creation of civil societies and has also contributed to the birth of a democracy that brings greater social justice.

Finally, the central question that we would like to develop is the degree of influence of the four factors mentioned above on the economic and social policy decision adopted by the government. We can say that this item has a mean of 3.86 with a standard deviation of 0.836 . This distribution is weakly skewed to the left $($ Skewnes $=-0.411)$ and a platykurtic kurtosis $($ Kurtosis $=-0.338)$.

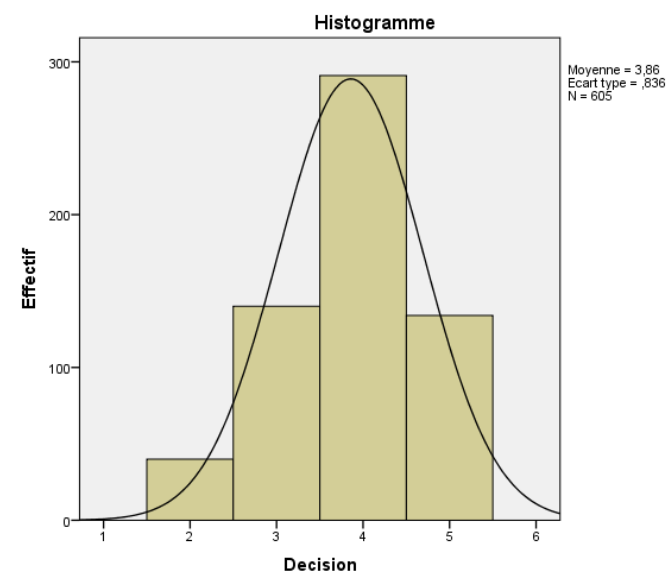

Figure 6: Histogram of the "economic and social policy decision" variable

The results show that the four factors exert more than average pressure on the economic and social policy decision adopted by the government (Mean $=3.86$ : between average and good). This means that the unification of the four types of lobby is a powerful pole capable of playing an important role on the political and social scene. It is thanks to the Tunisian revolution of 2011 that we have seen the emergence of a real lobbying capable of exerting pressure on government decisions. At the time of President Ben Ali, there was no strong lobbying because the dictatorial regime did not encourage the creation and diversity of different types of lobbying.

We now turn to the factor analysis to measure the reliability statistics where we found, with reference to Table 1, for the first variable which is "social media" that Cronbach's Alpha $=0.797>0.7$. Indeed, the factorization of the five items of the variable generated a significant reliability evaluated at 0.797 , making this factorization reliable. 
Revue europénnee du droit social

\begin{tabular}{|c|c|c|c|c|c|}
\hline \multicolumn{7}{|c|}{ Table 1: Factor analysis of the different factors } \\
\hline Variables & $\begin{array}{c}\text { Number } \\
\text { of items }\end{array}$ & $\begin{array}{c}\boldsymbol{\alpha} \\
\text { Cronbach }\end{array}$ & KMO & $\begin{array}{c}\text { Barlett's } \\
\text { sphericity }\end{array}$ & $\begin{array}{c}\text { \% of the } \\
\text { variance of } \\
\text { the first } \\
\text { factor }\end{array}$ \\
\hline Social media & 5 & 0.797 & 0.665 & $201.614^{* * *}$ & 61.59 \\
\hline $\begin{array}{c}\text { The opposition } \\
\text { parties }\end{array}$ & 6 & 0.783 & 0.641 & $499.230^{* * *}$ & 72.40 \\
\hline The unions & 6 & 0.745 & 0.668 & $1209.620^{* * *}$ & 64.34 \\
\hline Civil societies & 6 & 0.869 & 0.625 & $947.098^{* * *}$ & 75.94 \\
\hline
\end{tabular}

To validate the first factorization, the KMO index displays a value of 0.665 , showing the validity of this factorization. This is further justified by the high significance of Barlett's test of sphericity. The factorization of these four items generated a common factor explaining $61.590 \%$ of the total training.

For the second variable which is "opposition parties", the factorization of the 6 items of this variable generated a significant reliability evaluated at 0.783 , making this factorization reliable.

To validate the first factorization, the KMO index shows a value of 0.641 , showing the validity of this factorization. This is further justified by the high significance of Barlett's test of sphericity. The factorization of these six items generated a common factor explaining $72.402 \%$ of the total training.

For the third variable which is "unions", the factorization of the 6 items of this variable generated a significant reliability evaluated at 0.745 , making this factorization reliable.

To validate the first factorization, the KMO index shows a value of 0.668 , showing the validity of this factorization. This is further justified by the high significance of Barlett's test of sphericity. The factorization of these six items generated a common factor explaining $64.343 \%$ of the total training.

For the fourth variable which is "civil societies", the factorization of the 6 items of this variable generated a significant reliability evaluated at 0.869 , making this factorization reliable.

To validate the first factorization, the KMO index shows a value of 0.625 , showing the validity of this factorization. This is further justified by the high significance of Barlett's test of sphericity. The factorization of these six items generated a common factor explaining $75.942 \%$ of the total training.

\subsection{Model Estimation}

After factoring the above four variables, we opted to determine their effects on the decision. However, given the large difference in the responses of the different stakeholders, we corrected this individual heteroscedasticity through the estimation of a multinomial logit model. 
In this estimation, three modalities $(2,3$ and 4$)$ were able to give satisfactory results. However, the extreme modalities (1 and 5) have low frequencies and do not allow efficient estimates.

\begin{tabular}{|c|c|c|c|c|c|c|c|c|}
\hline & \multirow[b]{2}{*}{ Decision } & \multirow[b]{2}{*}{ B } & \multirow{2}{*}{$\begin{array}{l}\text { Standard } \\
\text { deviation }\end{array}$} & \multirow[b]{2}{*}{ Wald } & \multirow[b]{2}{*}{ Significance } & \multirow[b]{2}{*}{$\operatorname{Exp}(B)$} & \multicolumn{2}{|c|}{ 95\% Confidence Interval } \\
\hline & & & & & & & $\begin{array}{c}\text { Lower } \\
\text { terminal }\end{array}$ & Upper terminal \\
\hline \multirow{7}{*}{2} & Constant & -1.281 & 0.237 & 29.204 & 0.000 & & & \\
\hline & MS & -0.549 & 0.226 & 5.908 & 0.015 & 0.577 & 0.371 & 0.899 \\
\hline & $\mathrm{PO}$ & 1.043 & 0.208 & 25.188 & 0.000 & 2.839 & 1.889 & 4.267 \\
\hline & SYND & -1.178 & 0.218 & 29.193 & 0.000 & 0.308 & 0.201 & 0.472 \\
\hline & $\mathrm{SC}$ & -0.571 & 0.201 & 8.032 & 0.005 & 0.565 & 0.381 & 0.839 \\
\hline & Constant & 0.269 & 0.142 & 3.561 & 0.059 & & & \\
\hline & MS & -0.257 & 0.118 & 4.733 & 0.030 & 0.773 & 0.613 & 0.975 \\
\hline \multirow[t]{5}{*}{3} & $\mathrm{PO}$ & 0.389 & 0.144 & 7.252 & 0.007 & 1.475 & 1.112 & 1.958 \\
\hline & SYND & -0.415 & 0.169 & 6.068 & 0.014 & 0.660 & 0.475 & 0.919 \\
\hline & $\mathrm{SC}$ & -0.594 & 0.160 & 13.690 & 0.000 & 0.552 & 0.403 & 0.756 \\
\hline & Constant & 1.029 & 0.126 & 66.764 & 0.000 & & & \\
\hline & MS & -0.133 & 0.108 & 1.515 & 0.218 & 0.875 & 0.708 & 1.082 \\
\hline \multirow[t]{3}{*}{4} & PO & 0.677 & 0.127 & 28.376 & 0.000 & 1.967 & 1.534 & 2.524 \\
\hline & SYND & -0.781 & 0.147 & 28.185 & 0.000 & 0.458 & 0.343 & 0.611 \\
\hline & $\mathrm{SC}$ & -0.195 & 0.146 & 1.774 & 0.183 & 0.823 & 0.618 & 1.096 \\
\hline
\end{tabular}

At the decision 2 level, social media (SM) and trade unions (SYND) show negative and significant effects relatively at $5 \%$ and $1 \%$. However, opposition parties (OP) and civil societies (CS) show positive and significant effects at $1 \%$.

At the decision 3 level, social media (SM), trade unions (SYND) and civil societies (SC) show negative and significant effects relative to 5\% and $1 \%$. However, opposition parties (OP) show positive and significant effects at $1 \%$.

For decision 4, trade unions (SYND) show negative and significant effects at $1 \%$. In contrast, opposition parties (OP) show positive and significant effects at $1 \%$. However, social media (SM) and civil societies (CS) have no significant effects on this decision.

Similarly, we report low adjustment values where the results show us the Cox and Snell ratio (0.189), the Nagelkerke ratio (0.208) and finally the McFadden ratio (0.287).

This can be explained by the high heterogeneity of the sample.

From the results, it can be said that social media exerts pressure on the decision maker. Indeed, social media participated enormously in the popular protest movement that brought about the fall of the regime of the dictatorial president Ben Ali. It is especially, the social network "Facebook" which was a triggering factor of the Tunisian revolution. The fact that this new form of lobbying is uncontrollable by the government of Ben Ali who was unable to eliminate the pressure exerted by 
Internet users. The Tunisian example triggered the beginning of a revolutionary wave in the Arab world under the name of the "Arab Spring".

The "e-lobbying" has become a great power capable of upsetting the political world by spreading information and images that can influence the public opinion. Every politician has to fear this new form of lobbying because the information is addressed to the whole world: this can be a positive asset for democracy. The elobbying is the representative of everybody: all internet users can use this new form of lobbying by distributing information or films in order to influence the public opinion or to exploit it for contesting purposes.

Moreover, this new form of lobbying continues to animate the political and social scene by openly criticizing government decisions. Indeed, the problem of the Coronavirus pandemic has animated the social networks by criticizing the Tunisian government on the delay of vaccination against the Covid-19 and the poor management of this health crisis: the anger does not stop rising in Tunisia.

The results also show that there is no strong opposition capable of influencing the government's decisions. This is explained by the lack of agreement among the political parties to form a bloc of opposition parties capable of changing the government's decisions: the political parties did not succeed in unifying their ranks, especially during the legislative and presidential elections. The opposition parties have never taken the same position in criticizing the government's decisions. This dispersion of the opposition parties is mainly due to the different ideological tendencies of these parties, leading to a desire on the part of their leaders to distinguish themselves.

Similarly, the results also show that the unions exert strong pressure on the government's decisions. This is justified by the existence of a powerful union, the Tunisian General Labor Union (UGTT). Indeed, the important role played by this organization has contributed enormously to the political, economic and social stability of the country. Since January 20, 1946, the UGTT has been considered as the first trade union movement in the struggle for national independence. At the time of Presidents Bourguiba and Ben Ali, the UGTT did not hesitate to replace the opposition parties by rejecting the government's decisions in the name of the general interest and the interest of its workers. At the beginning of the Tunisian revolution, the UGTT agreed to participate in a "government of national unity": this proves that there is great confidence in this organization and that the presence of this union is mandatory for the achievement of social peace for a certain period.

The results also show that civil societies are exerting pressure on the government's decisions. It is thanks to the fall of the regime of Ben Ali that we have seen the creation of 2000 new associations, including about 700 after the elections of October 23, 2011, while the number of these associations was 9600 in 2010. This proves that there is more freedom in the associative life in Tunisia since we witness a liberalization of civil and political rights. The new law of 2011 on the creation of associations and more precisely the "Decree-Law 88" has allowed the simplification of administrative procedures in Tunisia. 
Civil societies have become dynamic actors in the political, economic and social fields since they can intervene in several subjects such as: freedom of expression, democracy and citizenship, human rights, social development and solidarity, gender equality, humanitarian action, local development, transparency and fight against corruption, good governance, environmental protection and sustainable development, etc. In the phase of a democratic transition, civil societies can participate in social development and thus freely protect the interests of Tunisian citizens by criticizing the government's decisions that are against the general interest.

To sum up, it can be said that the four forms of lobbying exert pressure on the government's decisions. Each form has its own means to influence the public opinion. The main point is that the government cannot make its decisions freely. It must be wary of all these forms of lobbying in order to avoid any confrontation or crisis that could damage the country. In recent decades, a new form of lobbying has emerged in the form of social media: the new information and communication techniques based on the Internet have created a powerful lobby capable of exerting great influence on the government's decisions.

The new political system adopted by the new constitution of January 2014 is severely criticized. This "mixed" political regime, which is based on a balance between legislative, executive and judicial powers, has not given satisfaction to the Tunisian people since economic and social problems such as unemployment, inequality, regional division remain as strong as before the revolution of January 14, 2011. This new regime is very complex because of the distribution of powers that has caused a confrontation between the various executive, legislative and judicial authorities.

\section{Conclusion}

E-lobbying is about getting the right message to the right person at the right time using new Internet technologies. Indeed, social media, such as Facebook, Twitter, yootube and Instagram, have animated political, economic and social life by exerting influence, or more precisely pressure, on the decision-maker. This new form of lobbying tries to influence the public opinion in order to defend ideas or, on the contrary, to fight against the decisions of the decision-maker. E-lobbying seeks to transform policies, attitudes and practices in favor of a given group.

For example, e-lobbying played an important role in the fall of the Tunisian dictatorship of Ben Ali through the creation of the "Jasmine" revolution of 2011. This new form of lobbying describes the path to a new democracy characterized by freedom of expression and freedom of choice for voters. The Tunisian revolution triggered the emergence of the so-called "Arab Spring".

After the failure of all Arab revolutions, the Tunisian revolution still remains the good example to follow even if there has been no great economic and social performance during the last ten years. It is true that the Tunisian democratic 
experience is now facing serious problems as political and social lobbies want to revise the constitution by replacing the hybrid parliamentary regime (half parliamentary and half presidential) with a presidential regime. The current political and social environment may create a crisis that will lead to the deterioration of the country's economic situation.

During the year 2020, the Tunisian economy experienced an $8.8 \%$ recession due to the coronavirus pandemic and the poor socio-political atmosphere. Instead of focusing on the fight against the spread of the Coronavirus through the search for the vaccine, the Tunisian government is trying to find solutions for the crisis and the political blockage that has become habitual. The absence of the Constitutional Court is undoubtedly the first reason for the existence of this blockage: the deputies of the Assembly of People's Representatives (ARP) must quickly create the Constitutional Court in order to solve the problem of political blockage.

To get Tunisia out of the current political crisis, we can give proposals: the first one is to make a change of the political regime and the constitution, as well. This change requires, according to article 143 of the constitution, an initiative of the President of the Republic or of a third of the members of the parliament. The second proposal is to repeat the experience of the quartet of national dialogue that won the Nobel Peace Prize in 2015: this quartet is composed of the Tunisian General Union of Labor, the Tunisian Union of Industry, Trade and Handicrafts, the Council of the Bar Association of Tunisia and the Tunisian League of Human Rights. The renewal of this experience will have for objective the organization of negotiations between the President of the Republic, the President of the Government and the President of the Assembly of the Representatives of the People in order to find a consensus that allows to solve the economic and social problems of the country.

\section{References}

- Arroyo Edward B. (2004) «Les lobbies dans la démocratie ». Revue Projet 2004/2 (n`279); pages 60 à 65.

- Bardon pierre et Thierry Libaert (2012) «Le lobbying ». Collection: Les Topos; Dunod

- Burdeau Georges (1982) «Traité de science politique: Tome III ». La dynamique politique: Volume I. Les forces politiques; Paris, LDGI, 3ème édition; $p 260$.

- De Beaufort (2019) «Du lobbying au E-lobbying ». Larcier- № 4- Regards d'experts MSdaim ESSEC.

- Farnel.Frank-J (1994) «Le lobbying: stratégies et techniques d'intervention ». Les éditions d'organisation.

- Foucraut Elsa (2019) « Pour un meilleur encadrement du lobbying ». Editeur: Transparency International France.

- Foster David (2021) «Testing theories of lobbying ». University of California, Berkeley (Foster@berkeley.edu). March 25.

- Greenwood J. (2003), Interest representation in the European Union, Basingstoke, Palgrave, Macmillan.

- Grossman Emiliano et Saurugger Sabine (2006) «Les groupes d'intérêt au secours de la démocratie? », Revue française de science politique 2/ (Vol. 56), p. 299-321 
- Grossman Emiliano et Saurugger Sabine (2004) «Les groupes d'intérêt français: entre exception française, l'Europe et le monde ", Revue internationale de politique comparée, 11 (4), 2004, p. 523

- Grunberg Gérard et Mayer Nonna (2003) «Démocratie représentative, démocratie participative », dans Pascal Perrineau (dir.), Le désenchantement démocratique, La Tour d'Aigues, Éditions de l'Aube, p. 215-230.

- Jennar Marc Raoul (2005) «Le gouvernement des lobbies: la gouvernance contre la démocratie ", in BALANYA

- Mayer Nonna (2002) «Les dimensions de la confiance », dans Gérard Grunberg, Nonna Mayer, Paul Sniderman, La démocratie à l'épreuve. Une nouvelle approche de l'opinion des Français, Paris, Presses de Sciences Po, p. 89

- Polère Cédric (2007) « Lobbying: l'influence des groupes d'intérêt s'accroît, et favorise une transformation de notre modèle démocratique ». Millenaire; Centre Ressources Perspectives et Grand lion.

- Saurugger Sabine (2003) «Les groupes d'intérêts entre démocratie associative et mécanismes de contrôle ». Raisons Politiques, 10, mai, p. 151-169.

- Vergniolle de Chantal, Sharon Begley et Florence Autret (2008) « Le lobbying, fléau ou mutation de la démocratie? ». Revue Chronique de la gouvernance N²008. 